\title{
ANALISIS PENGETAHUAN DAN SIKAP IBU TERHADAP PENCEGAHAN STUNTING PADA ANAK DI MASA PANDEMI COVID -19 DI KELURAHAN KORONG GADANG
}

\author{
MONA ARIESTIA \\ Akademi Keperawatan Kesdam I/BB Padang \\ Email : monaariestia03@gmail.com
}

\begin{abstract}
ABSTRAK
Stunting merupakan penggambaran dari status gizi kurang yang bersifat kronik pada masa pertumbuhan dan perkembangan sejak awal kehidupan. Dalam wawancara yang dilakukan di Kelurahan Korong Gadang ditemukan sepuluh ibu yang belum mengetahui tentang arti stunting, dua di antaranya pernah mendengar tetapi tidak tahu tentang stunting dan delapan di antaranya belum pernah mendengar tentang stunting. Penelitian ini dilakukan untuk mengetahui bagaimana pengetahuan dan sikap ibu terhadap pencegahan stunting pada anak di masa pandemi Covid-19. Populasi dalam penelitian ini adalah ibu-ibu yang mempunyai anak dibawah usia 10 tahun yang ada di Kelurahan Korong Gadang. Teknik pengambilan sampel yang digunakan dalam penelitian ini adalah random sampling sebanyak $30 \mathrm{ibu}$. Instrumen penelitian ini menggunakan kuesioner. Teknik analisis data yang digunakan adalah analisis bivariat dengan menggunakan uji Chi-Square. Hasil penelitian menunjukkan dari 30 ibu 22 atau (74\%) memiliki pengetahuan rendah, dan 8 atau (26\%) pengetahuan tinggi, dan hasil penelitian ini juga menunjukan bahwa hasil sikap ibu yaitu yang positif $23(76 \%)$ dan Negatif $7(24 \%)$ hasil penelitian ini juga menunjukan hasil ada hubungan yang bermakna antara pengetahuan dan sikap ibu terhadap pencegahan stunting pada anak di kelurahan korong gadang.
\end{abstract}

Kata kunci : pengetahuan, sikap, stunting, status gizi.

\begin{abstract}
Stunting is a description of chronic malnutrition in the period of growth and development since early life. The interviews conducted in Korong Gadang Sub-District never did ten mothers who had never known about the meaning of stunting, two of whom had heard of but did not know about stunting and eight of them had never heard of stunting. This research was conducted to see how the knowledge and attitudes of mothers towards preventing stunting in children during the Covid-19 pandemic. The population in this study were mothers who had children under the age of 10 in Korong Gadang Village. The sampling technique used in this study was random sampling of 30 mothers. This research instrument using a questionnaire. The data analysis technique used is bivariate analysis using the Chi-Square test. The results showed that of 30 mothers 22 or (74\%) had low knowledge, and 8 or (26\%) had high knowledge, and the results of this study also showed that the results of maternal attitudes were positive 23 (76\%) and negative 7 (24\%). ) The results also show that there is a close relationship with the knowledge and attitudes of mothers towards preventing stunting in children in the Korong Gadang Village.
\end{abstract}

Key words: knowledge, attitude, stunting, nutritional status. 


\section{PENDAHULUAN}

Stunting menggambarkan status gizi kurang yang bersifat kronik pada masa pertumbuhan dan perkembangan sejak awal kehidupan. Keadaan ini dipresentasikan dengan nilai $z$ score tinggi badan menurut umur (TB/U) kurang dari 2 standar deviasi (SD) berdasarkan standar pertumbuhan menurut WHO (WHO, 2010).

Anak yang mengalami stunting dapat mengalami gangguan perkembangan fisik, mental, kognitif dan intelektual sehingga anak tidak mampu belajar secara optimal. Anak stunting mempunyai kemampuan kognitif yang rendah, jika tidak ditangani sebelum mencapai usia lima tahun dapat berdampak sampai usia dewasa dan berisiko mengalami kematian, serta wanita dewasa yang stunting berisiko melahirkan anak dengan BBLR (Suliastiningsih and Madi 2013).

Faktor yang berhubungan dengan terjadinya stunting adalah kurangnya asupan gizi saat ibu mengandung, bayi tidak diberikan ASI Eksklusif pada enam bulan pertama dan MPASI, status sosio-ekonomi yang rendah dalam keluarga, dan tingkat pendidikan ibu (Nadhiroh et al. 2010).

Salah satu hal yang menjadi faktor terjadinya stunting terhadap balita adalah tingkat pengetahuan keluarga mengenai asupan gizi dan tingkat pendidikan dari orang tua yang mempengaruhi pola pikir (Mugianti et al. 2018).

Stunting mulai dapat dikenali sejak anak berusia 2 tahun karena pertumbuhan linear dan perkembangan otak yang pesat yang terjadi di usia tersebut. Jika sudah berisiko stunting, hal tersebut dapat dicegah segera karena sebelum usia lima tahun sudah sangat sulit untuk memperbaiki stunting (Mugianti et al. 2018).

Tim Nasional Percepatan Penanggulangan Kemiskinan (2018) mencatat bahwa prevalens stunting di Indonesia berada pada peringkat 108 dari 132 negara. Sebelumnya, Indonesia tercatat sebagai salah satu dari 17 negara yang mengalami beban ganda gizi, baik kelebihan maupun kekurangan gizi.

Di kawasan Asia Tenggara, prevalensi stunting di Indonesia Di kawasan Asia Tenggara, prevalensi stunting di Indonesia merupakan tertinggi kedua setelah Kamboja. Hasil Kementerian Kesehatan RI Badan Penelitian dan Pengembangan (2018), menunjukkan penurunan prevalensi stunting.

Pada bulan desember 2019 pandemi covid-19 sudah menyebar luas sampai saat ini di tahun 2020. Salah satu cara untuk menghentikan penebaran virus ini yaitu dengan adannya sosial distancing yang akhirnya membuat presiden republik indonesia memerintahkan untuk adannya PSBB secara besar besaran. Hal ini bukan hanya mempengaruhi masalah kesehatan masyarakat tetapi masalah ekonomi dimasyarakat juga terganggu oleh hal ini.

Dampak masalah ekonomi ini tentunya mempengaruhi pemberian gizi seimbang pada anak dan keluarga. Apalagi keluarga dengan ekonomi menengah kebawah, pasti sangat sulit sekali untuk memberikan gizi seimbang tersebut.

Tetapi karena masalah ekonomi tersebut, membuat masyarakat tidak dapat memberikan gizi yang baik. Tetapi walaupun dengan begitu kebutuhan gizi anak harus tetap dipenuhi. Karena untuk pencegahan masalah stunting pada anak di kemudian harinya. 
Maka dari itu diperulakannya pengetahuan yang baik untuk menunjang sikap yang baik daam pemenuhan gizi pada anak oleh ibu didalam rumah tangga. Oleh sebab itu maka peneliti tertarik untuk meneliti pengetahuan dan sikap dalam pencegahan stunting pada anak di Kelurahan Korong Gadang tahun 2020.

\section{METODE PENELITIAN}

Metode penelitian yang digunakan dalam penelitian ini adalah sampel diambil secara Random sampling sebanyak 30 Orang ibu. Data didapatkan dengan cara pengisian kuesioner yang telah disiapkan tekait Pengetahuan dan sikap ibu...Metode penelitian yang digunakan dalam penelitian ini adalah penelitian kuantitatif, dalam penelitian ini pengambilan sampel diambil secara Random sampling sebanyak 30 Orang ibu.

Data didapatkan dengan cara pengisian kuesioner yang telah disiapkan tekait Pengetahuan dan sikap ibu terhadap pencegahan terjadinya stunting.

Penelitian ini menggunakan dua jenis analisis data yaitu univariat untuk mendapatkan data karakteristik responden, Analisis pengetahuan ibu, gambaran sikap ibu, dan bivariat dengan menggunakan teknik uji Chi-Square untuk mengetahui hubungan pengetahuan ibu dan sikap ibu dengan pencegahan stunting.

\section{Hasil}

Dalam penelitian ini untuk hasil distribusi karakteristik ressponden dapat dikelompokan dalam tabel berikut ini;
Tabel 1. Distribusi karekteristik responden

\begin{tabular}{lcc}
\hline Kategori & $\begin{array}{c}\text { Frekuensi } \\
\text { (n) }\end{array}$ & $\begin{array}{c}\text { Persentase } \\
\text { (\%) }\end{array}$ \\
\hline Usia ibu & & \\
22-33 tahun & 6 & $20 \%$ \\
$30-40$ tahun & 15 & $50 \%$ \\
$40-50$ tahun & 9 & $30 \%$ \\
\hline Pendidikan & & \\
Tamat SMP & 6 & $20 \%$ \\
Tamat SMA & 21 & $70 \%$ \\
$\begin{array}{l}\text { DIII/ sarjana/ } \\
\text { S2 }\end{array}$ & 3 & $10 \%$ \\
$\begin{array}{l}\text { Pekerjaan ibu } \\
\text { Tidak bekerja/ }\end{array}$ & 22 & \\
ibu RT & & \\
Karyawan & 8 & $26 \%$ \\
swasta/ PNS & &
\end{tabular}

Berdasarkan tabel 1 terlihat bahwa usia ibu mayoritas berada dalam kategori 30-40 tahun yaitu sebanyak 15 responden (50\%) Sebagian besar tingkat pendidikan responden adalah tamatan SMA yaitu 21 responden (70\%). Lebih dari setengah responden tidak bekerja/ ibu RT yaitu sebanyak 22 responden (74\%).

Dalam penelitian ini untuk hasil pengetahuan responden dapat dikelompokan dalam tabel berikut ini;

Tabel 2

Analisis pengetahuan ibu terhadap pencegahan stunting pada anak

\begin{tabular}{lcc}
\hline Kategori & $\begin{array}{c}\text { Frekuensi } \\
\text { (n) }\end{array}$ & $\begin{array}{c}\text { Persentase } \\
\text { (\%) }\end{array}$ \\
\hline Tinggi & 8 & $26 \%$ \\
Rendah & 22 & $74 \%$ \\
Total & 30 & 100,0 \\
\hline
\end{tabular}

Berdasarkan tabel 2. Terlihat bahwa mayoritas ibu memiliki pengetahuan rendah tentang pencegahan stuting yaitu sebanyak 22 responden atau (74\%). 
Dalam penelitian ini untuk hasil sikap ibu dapat dikelompokan dalam tabel berikut ini;

\section{Tabel 3}

\section{Analisis sikap ibu terhadap pencegahan} stunting pada anak

\begin{tabular}{lcc}
\hline Kategori & $\begin{array}{c}\text { Frekuensi } \\
\text { (n) }\end{array}$ & $\begin{array}{c}\text { Persentase } \\
(\%)\end{array}$ \\
\hline Positif & 23 & $76 \%$ \\
Negatif & 7 & $24 \%$ \\
Total & 30 & 100,0 \\
\hline
\end{tabular}

Berdasarkan tabel 3. Terlihat bahwa mayoritas Responden Memiliki sifat positif tentang pencegahan stunting pada anak sebanyak 23 atau (76 \%).

Dalam penelitian ini untuk hasil sikap ibu dapat dikelompokan dalam tabel berikut ini;

\section{Tabel 4}

Analisis hubungan pengetahuan dan sikap ibu terhadap pencegahan stunting pada anak

\begin{tabular}{|l|c|c|c|c|c|c|}
\hline \multirow{2}{*}{$\begin{array}{l}\text { Penget } \\
\text { a }\end{array}$} & \multicolumn{4}{|c|}{ Sikap } & \multirow{2}{*}{ Total } & \multirow{2}{*}{$\%$} \\
\cline { 2 - 5 } & Positif & \multicolumn{2}{|c|}{ Negatif } & & \\
\cline { 2 - 5 } & $\mathbf{F}$ & $\%$ & $\mathbf{F}$ & $\%$ & & \\
\hline Rendah & 7 & 31,8 & 15 & 68,2 & 22 & $100 \%$ \\
\hline Tinggi & 5 & 62,5 & 3 & 37,5 & 8 & $100 \%$ \\
\hline Total & 8 & & 22 & & 30 & $100 \%$ \\
\hline
\end{tabular}

Berdasarkan tabel 4. Analisis hubungan pengetahuan dan sikap ibu terhadap pencegahan stunting didapatkan bahwa Pengetahuan ibu yang rendah memiliki sikap positif sebanyak 7 orang atau $(31,8)$ dan sikap negatif sebanyak 15 orang atau $(68,2$ $\%$. Sedangkan ibu yang memiliki pengetahuan tinggi yang memiliki sikap positif sebanyak 5 orang atau (62,5\%) dan yang memiliki sikap negatif sebanyak 3 orang atau $(37,5 \%)$.

\section{PEMBAHASAN}

Karekteristik responden
Temuan dalam penelitian ini menemukan bahwa mayoritas ibu berusia 30-40 tahun yaitu sebanyak 30 responden ( $50 \%$ ).

Hal ini menunjukkan bahwa ibu- ibu yang memiliki anak lebih didominasi oleh ibu-ibu yang berumur 30-40 tahun karena pada umur tersebut seorang wanita masih produktif untuk menghasilkan keturunan dengan aman. Menurut penelitian yang dilakukan oleh Susanti, (2012) rentang usia 30-40 tahun merupakan usia produktif untuk hamil dan aman untuk kehamilan dan persalinan karena kualitas sel telur yang baik dan meningkat kualitasnya serta kualitas otot dinding rahim yang masih kuat. Hal ini sejalan dengan penelitian yang dilakukan oleh Rahmandiani et al. (2019). mengenai hubungan pengetahuan ibu tentang stunting dengan karakteristik sumber informasi di Desa Hegarmanah Kecamatan Jatinangor Kabupaten Sumedang dimana jumlah responden terbanyak adalah ibu yang berusia 30-40 tahun yaitu sebanyak 130 responden (71,0\%). Berbeda dengan penelitian yang dilakukan Olsa et al. (2017).

Menurut Lailatul \& Ni'mah (2015) orang yang memiliki tingkat pendidikan baik dapat dengan mudah menerima informasi dan dapat memahami dengan baik informasi yang diterima. Hal ini sejalan dengan penelitian yang dilakukan oleh Anindita (2012) sebanyak 23 responden $(69,7 \%)$ memiliki pendidikan tingkat lanjut dan penelitian yang dilakukan oleh Septamarini dkk (2019) sebanyak 23 responden $(72,9 \%)$ memiliki tingkat pendidikan diploma. Namun penelitian ini tidak sejalan dengan penelitian Rahmandiani dkk (2019) mendapatkan responden yang memiliki pendidikan tertinggi adalah SMP yaitu sebanyak 107 ibu (44,2\%). Penelitian Basuki \& Uminingsih (2019) responden terbanyak berpendidikan SMA yaitu 45 ibu (60\%). 
Sedangkan penelitian yang dilakukan oleh Pribadi dkk (2019) kebanyakan responden memiliki pendidikan tertinggi yaitu SD sebanyak 24 responden (47,1\%). Dalam penelitian ini didapatkan hasil bahwa mayoritas responden tidak memiliki pekerjaan atau sebagai ibu rumah tangga yaitu sebanyak 34 responden (57,6\%). Hal ini menunjukkan bahwa ibu-ibu tersebut lebih fokus dalam membantu pekerjaan rumah tangga, serta fokus dalam merawat anak dari pada bekerja di luar rumah. Padahal ibu-ibu tersebut lebih banyak lulusan dari perguruan tinggi dan masih berada dalam usia produktif yang dapat bekerja diluar rumah selain menjadi ibu rumah tangga. Menurut Krisnawati,dkk (2017) terdapat beberapa hal yang melatarbelakangi seorang ibu yang lulusan perguruan tinggi tetapi tetap memiliki untuk menjadi ibu rumah tangga, yaitu : tidak sanggup menjalankan peran ganda, memiliki penilaian terhadap penghasilan perempuan yang walaupun memiliki hal pendidikan dan pengalaman serta keterampilan kerja namun tetap akan mendapatkan ladang pekerjaan yang rendah, penghasilan suami sudah mencukupi, tidak diperbolehkan suami untuk bekerja, dan fokus merawat anak

\section{Sikap}

Lebih dari setengah responden memiliki sikap yang positif yaitu responden (74\%). Sikap positif yang dimiliki ibu tidak terlepas dari pengetahuan atau informasi yang telah diperoleh dan pengetahuan yang dimiliki ibu sangatlah baik atau dalam kategori tinggi sehingga hal tersebut membentuk sikap positif atau penilaian ibu yang baik terhadap kejadian stunting. Menurut Haines dkk (2018) Sikap ibu terhadap stunting adalah persepsi ibu mengenai dampak stunting terhadap anak
Hal ini sejalan dengan penelitian yang dilakukan oleh Setyowati (2018) sebanyak 21 responden $(61,8 \%)$ tidak memiliki pekerjaan dan penelitian yang dilakukan oleh Fauzi dkk (2020) sebanyak 87 responden (91,6\%) sebagai ibu rumah tangga. Namun hasil yang berbeda didapatkan dalam penelitian yang dilakukan oleh Rahmad \& Miko (2016) dimana sebagian besar responden bekerja sebagai swasta yaitu 17 responden (50,0\%) dan penelitian yang dilakukan oleh Hasandi dkk (2019) mendapatkan hasil terbanyak responden bekerja sebagai petani yaitu 22 responden(42,3\%).

\section{Pengetahuan}

Sebagian besar responden memiliki pengetahuan yang rendah tentang stunting yaitu sebanyak (74\%) Hal ini menunjukkan bahwa pengetahuan ibu masih kurang dalam pencegahan stunting. Karena mayoritas pendidikan tertinggi ibu dalam penelitian ini adalah SMA. Hal ini berbanding terbalik dengan penelitian Lailatul \& Ni'mah (2015) seorang ibu yang memiliki tingkat pendidikan yang baik akan dengan mudah menerima dan memproses informasi yang diterima dengan baik.

yang dapat menghasilkan sikap positif atau negatif dari ibu berdasarkan informasi yang diterima.

Menurut penelitian Olsa dkk (2017) yang mendapatkan hasil sebagian besar responden memiliki sikap yang positif yaitu 128 responden $(55,2 \%)$, begitu juga dengan penelitian yang dilakukan oleh Arnita dkk (2020) yang mendapatkan hasil terbanyak yaitu sikap yang baik sebanyak 59 .

Hubungan pengetahuan dan sikap ibu terhadap pencegahan stunting pada anak 
Vol.2.No 2 (2020)

p-ISSN :2657-2435

e-ISSSN:2721-3145

Peneliti berasumsi karena mayoritas ibu adalah lulusan SMA, sehingga memiliki kesempatan lebih dalam menerima informasi dan memahami dengan baik sehingga ibuibu tersebut memiliki tingkat pengetahuan yang tinggi mengenai stunting. Namun, dengan adanya pengetahuan yang baik atau tingkat pendidikan yang sudah baik tidak dapat menjamin bagaimana pola hidup seseorang dan tidak dapat menjamin sikap maupun perilaku yang baik. Jika pengetahuan ibu baik namun kondisi ekonominya tidak mendukung maka tidak seimbang dalam menerapkan pola hidup sehat.

Menurut Apriani (2018) menjelaskan bahwa ibu yang memiliki pendidikan tinggi akan mudah dalam menerima dan memahami informasi yang diberikan khususnya dalam memilih makanan yang bergizi, namun untuk memperoleh bahan pangan yang bergizi dipengaruhi juga oleh status ekonomi keluarga atau kemampuan keluarga dalam membeli bahan pangan yang bergizi. Sehingga, dengan memiliki pekerjaan yang baik saja, pengetahuan yang baik saja, atau pendapat yang sudah bagus belum dapat menentukan tingkat kesehatan dari seseorang, jadi harus seimbang antara halhal tersebut.

Menurut Ningsih dkk (2015) sikap merupakan respon yang masih belum terbuka terhadap suatu stimulus dan timbulnya keinginan untuk bertingkah laku atau bertindak terhadap suatu hal. Namun, sikap tidak selalu menghasilkan sebuah tindakan karena dipengaruhi oleh seberapa banyak pengalaman yang dialami seseorang.

Menurut Ningsih dkk (2015) sikap merupakan respon yang masih belum terbuka terhadap suatu stimulus dan timbulnya keinginan untuk bertingkah laku atau bertindak terhadap suatu hal. Namun, sikap tidak selalu menghasilkan sebuah tindakan karena dipengaruhi oleh seberapa banyak pengalaman yang dialami seseorang.

Hal ini sejalan dengan penelitian yang dilakukan oleh Ramdaniati (2018) dengan hasil uji bivariat antara variabel sikap dengan kejadian stunting didapatkan nilai $p$ - value 0,455 sehingga disimpulkan bahwa tidak adanya hubungan antara sikap dengan kejadian stunting.

\section{KESIMPULAN}

Temuan dalam penelitian ini menyatakan bahwa ada hubungan yang bermakna antara pengetahuan dan sikap ibu dengan Pencegahan stunting pada anak Namun walaupun seperti itu, kondisi stunting anak tetap harus menjadi perhatian dan perlu dicegah. Stunting tidak semata-mata menunjukkan perawakan yang kerdil namun juga menjadi kondisi yang mencemaskan karena pertumbuhan sel lain dan kinerja belajar anak dapat menurun. Jika kondisi ini terus menerus berlangsung maka dapat menurunkan kualitas dan produktivitas masa depan warga negara Indonesia.

\section{SARAN}

Peneliti merekomendasikan kepada institusi pendidikan agar tetap memberikan edukasi kepada masyarakat terlebih khususnya ibu perihal tentang stunting karena hasil dari penelitian ini masih menunjukkan terdapat kejadian stunting di korong gadang Kuranji Padang.

\section{REFERENSI}

Apriani, L. (2018). Hubungan Karakteristik Ibu, Pelaksanaan Keluarga Sadar Gizi (Kadarzi) Dan Perilaku Hidup Bersih Sehat (Phbs) Dengan Kejadian Stunting (Studi kasus pada baduta 6-23 bulan di Wilayah Kerja Puskesmas Pucang Sawit Kota Surakarta). Jurnal Kesehatan Masyarakat (e-Journal), 6(4), 198-205 
Agustiningrum, T., \& Rokhanawati, D. (2016). Hubungan karakteristik ibu dengan kejadian stunting pada balita usia 24-59 bulan di wilayah kerja Puskesmas Wonosari I (Doctoral dissertation, Universitas' Aisyiyah Yogyakarta).

Anindita, P. (2012). Hubungan Tingkat Pendidikan Ibu, Pendapatan Keluarga, Kecukupan Protein \& Zinc dengan Stunting (Pendek) pada Balita Usia 6 35 Bulan di Kecamatan Tembalang Kota Semarang. Jurnal Kesehatan Masyarakat Universitas Diponegoro, 1(2), 18764

Apriani, L. (2018). Hubungan Karakteristik Ibu, Pelaksanaan Keluarga Sadar Gizi (Kadarzi) Dan Perilaku Hidup Bersih Sehat (Phbs) Dengan Kejadian Stunting (Studi kasus pada baduta 6-23 bulan di Wilayah Kerja Puskesmas Pucang Sawit Kota

SIHOMBING, Ida Mariana. ANALISIS TINGKAT PENGETAHUAN IBU HAMIL TENTANG PERDARAHAN ANTEPARTUM. Jurnal IImiah Cerebral Medika, 2020, 2.1: 1-1.

Kementerian Kesehatan RI Badan Penelitian dan Pengembangan. (2018). Hasil Utama Riset Kesehatan Dasar. In Kementrian Kesehatan Republik Indonesia. https://doi.org/1 Desember 2013 
